\title{
Urgences
}

\section{Re : nom(s)}

\section{Renald Bérubé}

Numéro 15, octobre 1986

Épigraphiques

URI : https://id.erudit.org/iderudit/025313ar

DOI : https://doi.org/10.7202/025313ar

Aller au sommaire du numéro

Éditeur(s)

Urgences

ISSN

0226-9554 (imprimé)

1927-3924 (numérique)

Découvrir la revue

Citer ce document

Bérubé, R. (1986). Re : nom(s). Urgences, (15), 47-47.

https://doi.org/10.7202/025313ar

Ce document est protégé par la loi sur le droit d'auteur. L'utilisation des services d'Érudit (y compris la reproduction) est assujettie à sa politique d'utilisation que vous pouvez consulter en ligne.

https://apropos.erudit.org/fr/usagers/politique-dutilisation/ 


\title{
Renald Bérubé \\ RE: $\operatorname{NOM}(S)$
}

\begin{abstract}
Il a dissimulé son propre nom, un beau nom, William [Shakespeare], dans ses pièces [...] Qu'y-a-t-i] dans un nom? C'est ce que nous nous demandons quand nous sommes enfants en écrivant ce nom qu'on nous dit être le nôtre.
\end{abstract}

James Joyce: Ulysse

(Porter un nom. Un macaron, un vêtement, une bannière, un bandeau, un fardeau. Mon nom est, je me nomme, je suis, je signe mais qu'y a-t-il dans un nom, dissimulé, inconnu à (re)connaître, à (re)simuler sans toujours le savoir, miroir et mimétisme, qui suis-je, poids et joie de la quête sans fin et des découvertes à la petite journée? L'enfant jamais ne meurt qui écrit et qui lit, interrogation continue, qui suis-je en ce nom qu'on m'a donné, me fait porter, que je porte, qui suis-je en mon nom?)

Légende du long Irlandais: "Je suis James Joyce", dit-il impérativement, impécunieux et inconnu, en entrant au théâtre sans payer, nouveau shake-scene. Affirmation, assurance. Un beau nom, James. Mais tant d'absolu ne va pas sans laisser des doutes. Et Joyce, James, c'est-à-dire Jacob l'astucieux de l'Ancien Testament, traçant son propre portrait d'artiste encore jeune, allait devenir Dedalus, créateur du labyrinthe, puis écrire l'odyssée dublinoise d'Ulysse le rusé (permettant à Dedalus, au détour, d'expliquer Hamlet). James (Jacob)Dedalus-Ulysse: ruses, aventures et errances par mers et par mots, (r)éveiller Finnegan, et retrouver, avec Pénélope emmêlant démêlant ses propres écheveaux, l'Ithaque ou l'Irlande natale. Au prix de l'exil et de la cécité - exil et cécité, Joyce, chez lui, en toute lucidité. 